\title{
Efektivitas limbah cair pemindangan ikan dalam ransum terhadap performan itik persilangan Mojosari Peking
}

\section{The effectiveness of liquid waste fish preservation in ration on per- formance of Mojosari Pekin cross duck}

\author{
Achmad Sifai*, Luthfi Djauhari Mahfudz dan Warsono Sarengat \\ Fakultas Peternakan dan Pertanian Universitas Diponegoro Semarang
}

Submitted: 01 August 2017, Accepted : 09 September 2017

\begin{abstract}
ABSTRAK: Penelitian ini bertujuan untuk mengkaji efektivitas penggunaan limbah cair pemindangan ikan dalam ransum terhadap performan itik persilangan Mojosari - Peking. Materi yang digunakan adalah 120 ekor itik persilangan Mojosari - Peking jantan umur 3 minggu dengan bobot badan awal rata - rata 520,30 $\pm 57,82 \mathrm{~g}$. Rancangan percobaan yang digunakan adalah Rancangan Acak Lengkap (RAL) dengan 4 perlakuan dan 5 ulangan, masing - masing ulangan terdiri dari 6 ekor itik. Perlakuan yang digunakan adalah penggunaan limbah cair pemindangan ikan sebagai berikut : $\mathrm{T} 0=0 \%, \mathrm{~T} 1=$ $2,5 \%, \mathrm{~T} 2=5 \%$ dan $\mathrm{T} 3=7,5 \%$. Data yang diperoleh dianalisis menggunakan analisis variansi dan uji F pada taraf 5\% kemudian dilanjutkan uji wilayah ganda Duncan jika ada pengaruh perlakuan. Hasil penelitian menunjukkan bahwa penggunaan limbah cair pemindangan ikan hingga taraf $7,5 \%$ tidak berpengaruh nyata $(\mathrm{P}>0,05)$ terhadap konsumsi ransum, pertambahan bobot badan dan konversi ransum, tetapi Income Over Feed Cost (IOFC) meningkat dengan penggunaan limbah cair pemindangan ikan hingga taraf $5 \%$. Kesimpulan dari penelitian ini adalah penggunaan limbah cair pemindangan ikan paling efektif yaitu sebesar $2,5 \%$.
\end{abstract}

Kata kunci : itik persilangan Mojosari - Peking, limbah cair pemindangan ikan dan Performan.

ABSTRACT: The aim of this research was to examined the effectiveness of the used of liquid waste fish preservation in the ration on performance of Mojosari - Pekin crossing duck age 3 - 8 weeks. The material used 120 of male Mojosari - Pekin crossing ducks 3 weeks with an average body weight of $520.30 \pm 57.82$ g. The experimental design used was Completely Randomized Design (RAL) with 4 treatments and 5 replications, each replications consisted of 6 ducks. The treatment used of liquid waste fish preservation as follows: $\mathrm{T} 0=0 \%, \mathrm{~T} 1=2.5 \%, \mathrm{~T} 2=5 \%$ and $\mathrm{T} 3=7.5 \%$. The data obtained were analyzed using analysis of variance and F test at $5 \%$ level then continued Duncan double area test if there was effect of treatment. The results showed that the use of liquid waste fish preservation up to $7,5 \%$ level did not have significant effect $(\mathrm{P}>0,05)$ on ration consumption, body weight gain and ration conversion, but income over feed cost (IOFC) increased with the use of liquid waste fish preservation up to $5 \%$ level. The conclusion of this research is the most effective using liquid waste fish preservation is $2,5 \%$.

Keywords : Mojosari - Pekin cross duck, liquid waste fish preservation and Performance.

\footnotetext{
* Corresponding author: achmadsifai@gmail.com
} 


\section{PENDAHULUAN}

Produksi ikan pindang di Pesisir Utara Jawa tersebar mulai dari daerah Banten hingga Banyuwangi. Berdasarkan data Kementerian Perindustrian RI tahun 2016, tercatat lebih dari 105 industri pengolahan ikan pindang tersebar di wilayah pulau Jawa, diantaranya \pm 32 industri terdapat di Provinsi Jawa Tengah. Menurut data dari Kementerian Kelautan dan Perikanan pada tahun 2013 produksi ikan pindang di Indonesia mencapai 253.600 ton, dimana produksi ini diprediksi akan terus meningkat setiap tahun. Produksi yang melimpah ini menghasilkan limbah berupa cairan sisa rebusan ikan yang kandungan padatnya sebagian besar berupa lemak tidak jenuh. Selama ini limbah tersebut hanya dibuang begitu saja tanpa dilakukan pengolahan, sehingga mengakibatkan pencemaran lingkungan berupa bau menyengat yang ditimbulkan. Namun dalam limbah cair pemindangan ikan mengandung nutrisi berupa asam lemak esensial omega 3 dan omega 6.

Itik mengkonsumsi pakan lebih banyak dibandingkan ayam, sehingga biaya pakan yang dikeluarkan juga lebih tinggi. Pakan itik umumnya diberikan dalam bentuk basah, sesuai dengan morfologi paruh itik yang berbentuk pipih, sehingga pakan mudah untuk dikonsumsi dan mengurangi jumlah pakan yang tercecer (Arianti dan Ali, 2009). Melihat kondisi tersebut maka timbul sebuah gagasan untuk memanfaatkan limbah pemindangan ikan sebagai campuran untuk membasahi ransum itik. Selain dapat digunakan sebagai media untuk membasahi ransum, kandungan asam lemak esensial dalam limbah tersebut juga dapat digunakan sebagai suplemen pakan untuk menambah nafsu makan dan menunjang produktivitas ternak.

Asam lemak omega 3 memiliki

peran yang cukup baik dalam meningkatkan kesehatan ternak, seperti mencegah terjadinya peradangan, penggumpalan darah, hipertensi, mencegah penyakit jantung koroner, diabetes dan artritis (Simopoulus, 2009). Asam lemak omega 3 dan omega 6 juga memiliki peranan penting dalam proses metabolisme tubuh yaitu dapat meningkatkan penyerapan nutrisi dan memudahkan pengeluaran sisa metabolisme dari sel, sehingga akan meningkatkan performan ternak. Asam lemak esensial berperan penting dalam mendukung proses pertumbuhan dan perkembangan, karena asam lemak tersebut dibutuhkan untuk mendukung proses pembentukan sel-sel dalam syaraf, organ dan jaringan tubuh (Diana, 2012). Menurut Starcevic dkk. (2014) asam lemak esensial dapat digunakan sebagai suplemen pakan untuk meningkatkan kesehatan, menunjang pertumbuhan dan meningkatkan kualitas produk peternakan.

Berdasarkan uraian tersebut maka dilakukan penelitian menggunakan limbah cair pemindangan ikan untuk membasahi ransum itik sehingga akan meningkatkan produktivitas itik.

Tujuan dari penelitian ini adalah untuk mengkaji efektivitas penggunaan limbah cair pemindangan ikan dalam ransum terhadap performan itik Mojosari - Peking yang meliputi konsumsi ransum, pertambahan bobot badan, konversi ransum dan Income Over Feed Cost (IOFC).

\section{MATERI DAN METODE}

Penelitian ini dilaksanakan pada bulan Maret - Mei 2017 di kandang unggas Fakultas Peternakan dan Pertanian, Universitas Diponegoro, Semarang.

\section{Materi penelitian}

Materi yang digunakan dalam penelitian yaitu itik Persilangan Mojosari Peking (MP) jantan umur 3 Minggu sebanyak 120 ekor dengan bobot badan rata-rata sebesar 520,30 $\pm 57,82 \mathrm{~g}$. Limbah cair pemindangan ikan yang 
digunakan diperoleh dari industri pemindangan ikan di Desa Bajomulyo Kecamatan Juwana Kabupaten Pati. Kandang yang digunakan yaitu kandang brooder untuk pemeliharan awal DOD dan kandang koloni sistem postal yang terdiri dari 20 petak untuk kandang saat perlakuan. Peralatan yang digunakan antara lain timbangan untuk menimbang ternak dan menimbang bahan pakan, rangkaian lampu, tempat pakan, tempat minum, thermometer dan hygrometer untuk mengukur suhu dan kelembaban lingkungan kandang.

\section{Metode penelitian}

Metode penelitian terdiri dari tahap persiapan, perlakuan dan pengambilan data. Tahap persiapan meliputi pengadaan limbah cair pemindangan ikan yang diperoleh dari industri pemindangan di Desa Bajomulyo, Kecamatan Juwana Kabupaten Pati. Limbah cair pemindangan ikan selanjutnya dimasukkan dalam wadah kedap udara dan disimpan dalam lemari es untuk menjaga suhunya agar limbah tersebut tidak terkontaminasi dengan mikroorganisme yang dapat merusak sifat dan kandungan nutrisinya.
Pemeliharaan itik dilaksanakan selama 8 minggu. Selama 3 minggu awal DOD dipelihara pada kandang brooder dengan diberikan ransum jadi CP 511 sampai minggu kedua dan pada minggu ketiga dilakukan adaptasi ransum perlakuan. Bahan pakan yang digunakan untuk menyusun ransum perlakuan terdiri dari jagung, bekatul, konsentrat CP 144 dan limbah cair pemindangan ikan dengan kandungan energi metabolis dan protein yang disusun secara iso kalori dan protein. Kandungan nutrisi bahan pakan dan susunan ransum perlakuan dapat dilihat pada Tabel 1. dan Tabel 2.

Penelitian menggunakan

Rancangan Acak Lengkap (RAL) dengan 4 perlakuan dan 5 ulangan sehingga terdapat 20 unit percobaan, dan setiap unit percobaan terdiri dari 6 ekor itik. Perlakuan penggunaan limbah cair pemindangan ikan meliputi:

T0 = Ransum tanpa penambahan limbah cair pemindangan ikan

$\mathrm{T} 1$ = Ransum dengan 2,5\% limbah cair pemindangan ikan

$\mathrm{T} 2$ = Ransum dengan 5\% limbah cair pemindangan ikan

$\mathrm{T} 3=$ Ransum dengan 7,5\% limbah cair pemindangan ikan.

Tabel 1. Kandungan nutrisi bahan penyusun ransum

\begin{tabular}{|c|c|c|c|c|c|c|c|}
\hline \multirow{2}{*}{$\begin{array}{c}\text { Bahan Pa- } \\
\text { kan }\end{array}$} & \multirow{2}{*}{$\begin{array}{c}\left.\mathrm{EM}^{3}\right) \\
(\mathrm{Kkal} / \mathrm{kg})\end{array}$} & PK & SK & LK & $\mathbf{C a}$ & $\mathbf{P}$ & Abu \\
\hline & & \multicolumn{6}{|c|}{ 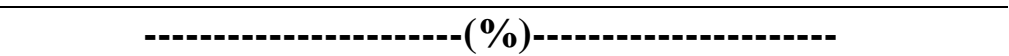 } \\
\hline $\begin{array}{l}\text { Limbah cair } \\
\text { pindang }\end{array}$ & $3981^{4)}$ & 0,32 & 0,18 & 10,95 & 0,002 & 0,00 & 0,08 \\
\hline Jagung ${ }^{2}$ & 3446 & 8,45 & 8,33 & 1,25 & 0,030 & 0,07 & 1,15 \\
\hline Konsentrat $^{2)}$ & 2500 & 37,00 & 6,00 & 2,00 & 12,000 & 1,20 & 35,00 \\
\hline Bekatul $^{2)}$ & 3405 & 12,50 & 16,70 & 14,34 & 0,003 & 0,00 & 8,19 \\
\hline $\begin{array}{l}\text { 1) } \mathrm{H} \\
\text { 2) } \mathrm{H} \\
\text { 3) } \mathrm{H} \\
\text { 4) } \mathrm{H} \\
\mathrm{F}\end{array}$ & $\begin{array}{l}\text { il Analisis } \\
11 \text { Analisis } \\
\text { il perhitun } \\
\text { il Perhitun }\end{array}$ & $\begin{array}{l}\text { oksima } \\
\text { oksima } \\
70 \% \\
\text { n ener }\end{array}$ & $\begin{array}{l}\text { borator } \\
\text { borator } \\
\text { Gross } \\
\text { erdasar }\end{array}$ & $\begin{array}{l}\text { n Terp } \\
\text { n Ilmu } \\
\text { ergy (S } \\
\text { rumu } \\
5 \text { J em. }\end{array}$ & $\begin{array}{l}\text { UNDII } \\
\text { trisi Pal } \\
\text { ble, } 20 \\
\text { alton }\end{array}$ & $\begin{array}{l}016 . \\
\text { UNDI } \\
\text { vohard }\end{array}$ & $\begin{array}{l}016 . \\
0,1982)\end{array}$ \\
\hline
\end{tabular}


Tabel 2. Kandungan nutrisi ransum perlakuan

\begin{tabular}{lcccc}
\hline \multirow{2}{*}{ Bahan Pakan } & \multicolumn{4}{c}{ Perlakuan } \\
\cline { 2 - 5 } & T0 & T1 & T2 & T3 \\
\cline { 2 - 5 } & \multicolumn{4}{c}{ T2-----------(\%)----------- } \\
\hline Limbah Cair Pindang & 0,00 & 2,50 & 5,00 & 7,50 \\
Jagung Kuning & 49,00 & 46,50 & 44,00 & 40,50 \\
Bekatul & 20,00 & 20,00 & 20,00 & 20,00 \\
Konsentrat & 31,00 & 31,00 & 31,00 & 32,00 \\
Total & 100,00 & 100,00 & 100,00 & 100,00 \\
Kandungan Nutrisi & & & & \\
Energi Metabolis (Kkal/kg) & $2.812,08$ & $2.844,57$ & $2.877,06$ & $2.906,25$ \\
Protein Kasar (\%) & 18,11 & 17,91 & 17,70 & 17,79 \\
Serat Kasar (\%) & 10,36 & 10,01 & 9,65 & 9,16 \\
Lemak Kasar (\%) & 4,22 & 4,47 & 4,71 & 4,95 \\
Kalsium (Ca) (\%) & 3,80 & 3,80 & 3,80 & 3,91 \\
Fosfor (P) (\%) & 0,82 & 0,82 & 0,81 & 0,82 \\
\hline Keterangan : Berdan
\end{tabular}

Keterangan : Berdasarkan hasil perhitungan nutrisi bahan penyusun ransum.

Tahap perlakuan itik dipelihara pada kandang sistem postal dengan dibagi menjadi 4 perlakuan dan 5 ulangan, setiap ulangan berisi 6 ekor itik. Itik diberikan ransum perlakuan dari umur 3-8 minggu. Ransum perlakuan yang diberikan berupa ransum semi basah dengan ditambahkan air. Pencampuran limbah cair pemindangan dalam ransum dilakukan saat ransum akan diberikan pada itik. Hal ini bertujuan untuk menghindari ransum agar tidak cepat basi. Pencampuran limbah cair pemindangan dalam ransum dilakukan dengan mencampurkan terlebih dahulu limbah cair pemindangan dengan air kemudian campuran tersebut dicampurkan dengan ransum yang akan diberikan. Metode ini digunakan agar limbah cair dapat tercampur merata dalam ransum. Pemberian pakan dilakukan 2 kali sehari yaitu pada pagi hari pukul 06.00 WIB dan sore hari pukul 15.00 WIB dengan air minum yang diberikan secara adlibitum.

Pengambilan data dilakukan mulai minggu ke 3 sampai minggu terakhir pengamatan. Variabel yang diamati meliputi konsumsi ransum, pertambahan bobot badan, konversi ransum dan Income Over Feed Cost
(IOFC).

1. Konsumsi Ransum

Konsumsi ransum (g/ekor) diperoleh dengan cara menghitung selisih antara jumlah ransum yang diberikan dengan jumlah ransum yang tersisa.

2. Pertambahan Bobot Badan

Pertambahan bobot badan (g/ekor) diperoleh dengan cara mengurangi bobot badan hari terakhir dengan hari pertama pengamatan.

3. Konversi Pakan

Konversi pakan dihutung dengan menggunakan rumus :

Konversi Pakan $=\frac{\text { Total Konsumsi }}{\text { Petambahan Bobot badan }}$

\section{Income Over Feed Cost (IOFC)}

IOFC dihitung dengan menggunakan rumus :

IOFC $=($ Harga $\times$ Bobot Akhir $)-($ Harga Ransum $\times$ Total Konsumsi)

Data yang diperoleh dianalisis dengan menggunakan analisis ragam atau analisis of variance (ANOVA) dengan uji $\mathrm{F}$ pada taraf 5\% untuk mengetahui pengaruh perlakuan. Apabila ada pengaruh perlakuan dilanjutkan dengan 
uji wilayah ganda Duncan (Steel and Torrie, 1993 dalam (Purba dan Ketaren, 2011)).

\section{HASIL DAN PEMBAHASAN}

Hasil penelitian menunjukkan bahwa rata - rata konsumsi ransum, pertambahan bobot badan, konversi ransum dan Income Over Feed Cost (IOFC) itik persilangan Mojosari Peking umur $3-8$ minggu dengan perlakuan penggunaan limbah cair pemindangan ikan dalam ransum dapat dilihat pada Tabel 3.

Tabel 3. Rata - rata konsumsi, pertambahan bobot badan, konversi ransum dan IOFC itik persilangan Mojosari Peking.

\begin{tabular}{lcccc}
\hline \multirow{2}{*}{ Parameter } & \multicolumn{4}{c}{ Perlakuan } \\
\cline { 2 - 5 } & T0 & T1 & T2 & T3 \\
\hline $\begin{array}{l}\text { Konsumsi Ransum } \\
\text { (gram) }\end{array}$ & $4.653,90$ & $4.730,63$ & $4.725,07$ & $4.735,30$ \\
$\begin{array}{l}\text { Pertambahan Bobot } \\
\text { Badan (gram) }\end{array}$ & 974,90 & $1.039,20$ & 938,03 & 825,34 \\
$\begin{array}{l}\text { Konversi Ransum } \\
\text { (IOFC) (Rp) }\end{array}$ & 4,83 & 4,61 & 5,08 & 5,74 \\
\hline Keterangan : Tina & $3.282,89$ & $4.956,42$ & $3.394,90$ & $1.418,97$ \\
\hline
\end{tabular}

Keterangan : Tidak berbeda nyata $(\mathrm{P}>0,05)$.

\section{Konsumsi ransum}

Berdasarkan hasil analisis statistik menunjukkan bahwa penggunaan limbah cair pemindangan ikan dalam ransum itik persilangan Mojosari - Peking tidak berpengaruh nyata $(\mathrm{P}>0,05)$ terhadap tingkat konsumsi ransum. Hasil yang tidak berbeda nyata ini disebabkan karena ransum yang diberikan mempunyai kandungan energi metabolis yang hampir sama, sehingga tidak mempengaruhi perbedaan tingkat konsumsi pada itik. Konsumsi pakan itik sangat berkaitan erat dengan kandungan energi yang terdapat di dalamnya, karena itik akan mengkonsumsi pakan untuk memenuhi kebutuhan energinya. Hal ini sesuai dengan pendapat Purba dkk. (2015), penggunaan ransum dengan kandungan energi metabolis yang hampir sama pada itik persilangan EPMP menghasilkan rataan konsumsi yang tidak berbeda. Menurut Widianto dkk. (2015), konsumsi ransum pada itik sangat dipengaruhi oleh kandungan nutrisi yang terdapat di dalamnya, khususnya kandungan energi, karena unggas memiliki sifat khusus yaitu mengkonsumsi pakan untuk memenuhi kebutuhan energinya. Hal yang sama juga dijelaskan oleh Scott dkk. (1992) bahwa semakin tinggi kandungan energi dalam ransum maka akan menyebabkan konsumsi semakin menurun, begitupun sebaliknya apabila kandungan energi dalam ransum rendah maka konsumsi akan meningkat.

Penggunaan limbah cair pemindangan ikan sampai taraf 7,5\% tidak mempengaruhi palatabilitas ransum sehingga konsumsi ransum itik relatif sama. Konsumsi ransum yang tidak berbeda nyata ini juga dipengaruhi oleh kondisi lingkungan, sistem pemeliharaan, jenis itik dan umur itik yang digunakan pada penelitian ini sama, sehingga itik mengkonsumsi ransum dengan jumlah yang sama pula. Menurut Dewanti (2007), umur itik yang sama menyebabkan kemampuan dalam mengkonsumsi pakan juga relatif sama, hal ini karena kemampuan saluran pencernaan itik terutama tembolok dalam menampung pakan relatif sama. Nafiu dan Pagala (2010) menyatakan bahwa konsumsi ransum pada ternak dapat dipengaruhi oleh beberapa faktor, diantaranya umur, kesehatan, kandungan nutrisi dalam ransum, temperatur lingkungan, jenis bahan pakan, kondisi ransum yang diberikan dan palatabilitas. 
Tabel 3. menunjukkan bahwa rata - rata konsumsi ransum berkisar antara 4.653,90 - 4.735,30 g/ekor. Hasil tersebut lebih tinggi dibandingkan dengan penelitian yang dilakukan Widianto dkk. (2015) bahwa konsumsi ransum pada itik Hibrida selama 40 hari berkisar antara 4.456,02 - 4.508,79 g/ekor. Konsumsi ransum yang lebih tinggi ini dikarenakan oleh kandungan asam lemak esensial dalam limbah cair pemindangan ikan yang menyebabkan terjadinya keseimbangan komposisi asam - asam lemak, sehingga meningkatkan konsumsi itik, meskipun belum berbeda nyata $(P>0,05)$. Menurut Iriyanti dkk. (2005), penambahan pakan yang mengandung asam lemak esensial akan menyebabkan keseimbangan komposisi asam - asam lemak sehingga pakan lebih palatable dan konsumsi ransum semakin meningkat. Dengan demikian penggunaan limbah cair pemindangan ikan dalam ransum dapat direspon dengan baik oleh itik dan tidak mempengaruhi efek negatif terhadap konsumsi itik.

\section{Pertambahan bobot badan}

Berdasarkan hasil analisis statistik menunjukkan bahwa penggunaan limbah cair pemindangan ikan dalam ransum itik persilangan Mojosari - Peking tidak berpengaruh nyata $(\mathrm{P}>0,05)$ terhadap pertambahan bobot badan. Pengaruh perlakuan yang tidak berbeda nyata ini disebabkan karena nutrisi dalam ransum masing - masing perlakuan mempunyai kandungan yang hampir sama, sehingga menghasilkan pertambahan bobot badan yang sama. Tidak adanya pengaruh yang nyata terhadap pertambahan bobot badan juga disebabkan karena tingkat konsumsi setiap perlakuan tidak berbeda nyata, sehingga nutrisi yang dapat dicerna oleh itik juga relatif sama. Menurut pendapat Agustina dkk. (2013), pertumbuhan itik sangat dipengaruhi oleh beberapa fakor, seperti konsumsi pakan, kandungan nutrisi dalam pakan, genetik, jenis kelamin, lingkungan dan manajemen pemeliharaan. Hal ini juga sejalan dengan pendapat Saleh dkk. (2006), bahwa kandungan nutrisi dalam pakan yang relatif sama serta tingkat konsumsi pakan yang tidak berbeda berakibat pada tidak adanya perbedaan pertambahan bobot badan itik.

Tabel 3. menunjukkan bahwa rata - rata pertambahan bobot badan itik persilangan Mojosari - Peking umur 3 8 minggu berkisar antara 825,34 $1.039,20$ g/ekor atau 23,58 - 29,69 g/ekor/hari. Hasil ini lebih tinggi jika dibandingkan dengan penelitian yang dilakukan oleh Widianto dkk. (2015) bahwa pertambahan bobot badan harian pada itik Hibrida berkisar antara 21,3925,16 g/ekor/hari. Hasil pertambahan bobot badan yang lebih tinggi pada penelitian ini dikarenakan oleh penggunaan limbah cair pemindangan ikan yang menyebabkan terjadinya keseimbangan asam-asam lemak, khususnya omega 3 dan omega 6 , sehingga menjadikan proses metabolisme dalam tubuh itik berlangsung optimal dan menghasilkan pertumbuhan yang lebih baik. Hal ini sesuai dengan pendapat Diana (2012) bahwa Asam lemak omega 3 memiliki peranan penting dalam proses metabolisme tubuh yaitu dapat meningkatkan penyerapan nutrisi dan memudahkan pengeluaran sisa metabolisme dari sel, sehingga pembentukan sel-sel dalam syaraf, organ dan jaringan tubuh berlangsung optimal. Wijiastuti (2013) menyatakan bahwa pemanfaatan omega 3 dalam pakan sangat tergantung pada keseimbangan asam-asam lemak yang lain, terutama imbangan omega 3 dengan omega 6 , sehingga omega 3 dapat dimanfaatkan oleh tubuh dengan baik serta fungsi fisiologis tubuh berjalan sempurna.

Hasil pertambahan bobot badan yang lebih tinggi dibandingkan dengan penelitian Widianto dkk. (2015) juga dipengaruhi oleh faktor genetik itik yang digunakan. Penelitian ini menggunakan itik persilangan Mojosari - Peking, dimana itik Peking merupakan jenis itik 
pedaging yang mempunyai kemampuan sangat baik dalam mengubah pakan menjadi daging, sehingga itik hasil persilangan Peking akan mewarisi sifat pertumbuhan dari induknya. Menurut Pamungkas dkk. (2013), selain asupan nutrisi, umur, jenis kelamin dan kesehatan, pertumbuhan itik juga sangat dipengaruhi oleh faktor genetik atau sifat yang diturunkan oleh tetuanya.

Penggunaan limbah cair pemindangan ikan yang semakin tinggi $(>2,5 \%)$ menyebabkan pertambahan bobot badan itik semakin rendah. Hal ini karena selain mengandung asam lemak esensial, limbah cair pemindangan ikan juga mengandung zat penghambat yang berupa kadar garam $(\mathrm{NaCl})$ yang cukup tinggi. Penggunaan limbah cair pemindangan ikan yang semakin tinggi mengakibatkan semakin meningkatnya kadar garam dalam ransum sehingga menyebabkan terganggunya fungsi ginjal dalam proses ekskresi yang mengakibatkan terganggunya proses metabolisme itik dan menyebabkan pertumbuhan itik yang kurang optimal. Menurut Tarmudji (2005), unggas sangat sensitif terhadap kadar garam dalam pakan, unggas yang mengkonsumsi garam secara berlebihan akan menyebabkan terjadinya keracunan dan timbulnya penyakit asites yang ditandai dengan gejala penumpukan cairan di bawah lapisan kulit, apabila kondisi ini dibiarkan maka dapat menyebabkan penurunan pertumbuhan bobot badan hingga kematian.

\section{Konversi ransum}

Berdasarkan hasil analisis statistik menunjukkan bahwa penggunaan limbah cair pemindangan ikan dalam ransum itik persilangan Mojosari - Peking tidak berpengaruh nyata $(\mathrm{P}>0,05)$ terhadap tingkat konversi ransum. Pengaruh perlakuan yang tidak berbeda nyata ini disebabkan karena tingkat konsumsi ransum dan pertambahan bobot badan pada masing - masing perlakuan juga tidak mengalami perbedaan yang nyata.
Konversi ransum sangat dipengaruhi oleh jumlah ransum yang dikonsumsi dan pertumbuhan bobot badan yang dihasilkan. Menurut Matitaputty dkk. (2011), konversi ransum memiliki hubungan erat dengan tingkat konsumsi dan pertumbuhan bobot badan ternak, semakin rendah konsumsi ransum dengan pertumbuhan bobot badan yang tinggi akan memperbaiki nilai konversi ransum.

Tabel. 3. Menunjukkan bahwa rata - rata konversi ransum itik persilangan Mojosari - Peking umur 3 8 minggu berkisar antara 4,61 - 5,74. Hasil tersebut sedikit lebih tinggi jika dibandingkan dengan penelitian yang dilakukan oleh Widianto dkk. (2015) bahwa konversi ransum itik Hibrida yang dipelihara selama 8 minggu berkisar antara 4,49 - 5,31. Menurut Herdiana dkk. (2014), konversi ransum dipengaruhi oleh beberapa faktor, seperti genetik, umur, bobot badan, kesehatan, keaktifan, jenis kelamin, konsumsi pakan, temperatur lingkungan dan kualitas pakan yang diberikan.

Konversi ransum menunjukkan suatu perbandingan antara jumlah ransum yang dikonsumsi untuk menghasilkan 1 $\mathrm{kg}$ pertambahan bobot badan. Nilai konversi ransum yang semakin tinggi menunjukkan bahwa semakin banyak konsumsi ransum yang dibutuhkan untuk meningkatkan bobot badan. Semakin rendah konversi ransum menunjukkan bahwa ransum yang digunakan memiliki kualitas yang baik dan efisien dalam menunjang proses pertumbuhan Hal ini sejalan dengan pendapat Widianto dkk. (2015) bahwa konversi ransum dapat dijadikan sebagai tolak ukur untuk mengetahui kualitas pakan dalam memenuhi kebutuhan nutrisi ternak. Suprijatna dkk. (2005) menyatakan bahwa semakin rendah nilai koversi ransum yang dihasilkan maka maka semakin baik karena ternak semakin efisien dalam memanfaatkan ransum yang diberikan. 


\section{Income Over Feed Coss (IOFC)}

Berdasarkan pada tabel 3 . diketahui bahwa rataan IOFC itik persilangan Mojosari - Peking sampai umur 8 minggu berturut - turut pada perlakuan T0, T1, T2 dan T3 sebesar 3.282,89, $4.956,42,3.394,90$ dan $1.418,93$. IOFC digunakan sebagai tolak ukur untuk melihat seberapa besar keuntungan yang diperoleh terhadap ransum yang digunakan. Menurut Saleh dkk. (2006), IOFC merupakan pendapatan yang diperoleh dari hasil penjualan produksi ternak dikurangi dengan total biaya pakan.

Tabel. 3. menunjukkan bahwa penggunaan limbah cair pemindangan pada perlakuan $\mathrm{T} 1(2,5 \%)$ dan T2 $(5 \%)$ menghasilkan IOFC yang lebih tinggi dibandingkan dengan ransum kontrol. Hal ini karena penggunaan limbah cair pemindangan ikan dalam ransum menyebabkan harga ransum menjadi lebih murah sehingga biaya produksi yang dikeluarkan dapat ditekan. Namun berbeda dengan perlakuan T3, meski ransum yang digunakan mempunyai harga yang lebih murah namun penggunaan limbah cair pemindangan sebanyak $7,5 \%$ ternyata menghasilkan IOFC yang lebih rendah dari ransum kontrol. Hal ini disebabkan karena pada perlakuan T3 menghasilkan pertambahan bobot badan yang paling rendah dibandingkan perlakuan lainnya, sehingga menyebabkan rendahnya nilai IOFC. Yamin (2008) menyebutkan bahwa nilai IOFC sangat ditentukan oleh pertambahan bobot badan yang dihasilkan, semakin tinggi pertambahan bobot badan, maka semakin besar pula nilai jual yang diperoleh. Menurut Christian dkk. (2016), nilai IOFC dipengaruhi oleh beberapa faktor, seperti bobot badan ternak, biaya pakan dan konversi pakan.

IOFC terbaik dihasilkan oleh perlakuan T1 yaitu sebesar 4.956,42. Hal ini disebabkan karena pada perlakuan tersebut mempunyai harga ransum yang murah dan menghasilkan pertambahan bobot badan yang tinggi, sehingga menyebab- kan tingginya nilai IOFC. Menurut Saleh dkk. (2006) bahwa untuk memperoleh IOFC yang tinggi dapat dilakukan dengan menekan biaya ransum dan memperbaiki konversi ransum.

\section{KESIMPULAN}

Penggunaan limbah cair pemindangan ikan hingga taraf 7,5\% ransum itik persilangan Mojosari Peking sampai umur 8 minggu secara signifikan belum dapat meningkatkan konsumsi ransum, pertambahan bobot badan dan konversi ransum itik, tetapi Income Over Feed Cost (IOFC) meningkat dengan penggunaan limbah cair pemindangan ikan sampai taraf $5 \%$. Penggunaan limbah cair pemindangan ikan paling efektif yaitu sebesar 2,5\% kerena menghasilkan performan yang terbaik.

\section{DAFTAR PUSTAKA}

Agustina, D., N. Iriyanti dan $\mathrm{S}$. Mugiyono. 2013. Pertumbuhan dan konsumsi pakan pada berbagai jenis itik lokal betina yang pakannya di suplementasi probiotik. J. Ilmiah Peternakan. 1 (2): $691-698$.

Arianti dan A. Ali. 2009. Performans itik pedaging (lokal x Peking) pada fase starter yang diberi pakan dengan persentase penambahan jumlah air yang berbeda. J. Peternakan. 6 (2): 71-77.

Christian, I. H. Djunaidi dan M. H. Natsir. 2016. Pengaruh penambahan tepung kemangi (Ocimum basilicum) sebagai aditif pakan terhadap penampilan produksi itik pedaging. J. Ternak Tropika. 17 (2): 34-41.

Dewanti, R. 2007. Potensi nutrisi tepung Azolla microphylla dalam memperbaiki performan itik Manila 
(Cairina moschata). Sains Peternakan. 5 (2): 12-17.

Diana, F. M. 2012. Omega 3. J. Kesehatan Masyarakat. 6 (2): 113-117.

Herdiana, R. M., Y. M. R. Dewanti dan Sudiyono. 2014. Pengaruh penggunaan ampas kecap dalam pakan terhadap pertambahan bobot badan harian, konversi pakan, rasio efisiensi protein, dan produksi karkas itik lokal jantan umur delapan minggu. Bul. Peternakan. 38 (3): 157-162.

Iriyanti, N., T. Yuwanta, Zuprizan dan S. Keman. 2005. Pengaruh penggunaan asam lemak rantai panjang dalam pakan terhadap penampilan dan profil darah serta gambaran ovarium ayam kampong betina. Buletin Peternakan. 29 (4): 177-184.

Matitaputty, P. R., R.R. Noor, P.S. Hardjosworo Dan C.H. Wijaya. 2011. Performa, persentase karkas dan nilai heterosis itik Alabio, Cihateup dan hasil persilangannya pada umur delapan minggu. J. Ilmu Ternak Dan Veteriner. 16 (2): 90-97.

Nafiu, L. O. dan M. A. Pagala. 2010. Pemberian keong Mas (Pomacea sp) dalam pakan terhadap penampilan itik Bali dan itik Tegal. Agripulus. 20 (1): 36-41.

Pamungkas, S. R., Ismoyowati dan S. A. Santosa. 2013. Kajian bobot tetas, bobot badan umur 4 dan 8 minggu serta korelasinya pada berbagai itik lokal (Anas plathyrynchos ) dan itik Manila (Cairina moscata) jantan. J. Ilmiah Peternakan. 1 (2): $488-500$.
Purba, M. dan P. P. Ketaren. 2011. Konsumsi dan konversi pakan itik lokal jantan umur delapan Minggu dengan penambahan Santoquin dan vitamin $\mathrm{E}$ dalam pakan. J. Ilmu Ternak dan Veteriner. 16 (4): 280-287.

Purba M, Haryati T, Sinurat AP. 2015. Performa itik pedaging EPMp dengan pemberian pakan yang mengandung berbagai level lisin selama periode starter. J. Ilmu Ternak dan Veteriner. 20 (1): 5863.

Saleh, E., T. Hestiwahyuni dan G. P. Siragih. 2006. Pemberian tepung bawang putih (Allium sativum 1.) dalam ransum terhadap performas itik Peking umur 1-8 minggu. J. Agribisnis Peternakan. 2 (3): 96100.

Schable, P. J. 2004. Poultry feed and nutrition. Departement of poultry series, Michigan State University East Lansing, Michigan. 198 198.

Scott, M. L., M. C. Nesheim dan R. I. Young. 1992. Nutrient of The Chickens. Scott Assoc Ithaca, New York.

Simopoulos, P. 2009. Commentary genetic variants and omega- 6 , omega-3 fatty acids their role in the determination of nutritional requirements and chronic disease risk. J. of Nutrigenetics and $\mathrm{Nu}-$ trigenomics. 2 (3):117-118.

Siswohardjono W. 1982. Beberapa metode pengukuran energi metabolis bahan makanan ternak pada itik. Institu Pertanian Bogor. Bogor. (Makalah Seminar Pasca Sarjana). 
Starcevic, K., T Masek, D. Brozic, N. Filipovic dan Z. Stojevic. 2014. Growth performance, serum lipids and fatty acid profile of different tissues in chicken broilers fed a diet supplemented with linseed oil during a prolonged fattening period. J. Veterinarski Arhiv. 84 (1): 75-84.

Suprijatna, E., U. Atmomarsono, dan R. Kartasudjana. 2005. Ilmu Dasar Ternak Unggas. Penebar Swadaya, Jakarta.

Tarmudji. 2005. Asites pada ayam pedaging. Wartazoa. 15 (1): 3848.

Widianto, B., H. S. Prayogi dan Nuryadi. 2015. Pengaruh penambahan tepung buah mengkudu (Morinda citrifolia L.) dalam pakan terhadap penampilan produksi itik Hibrida. J. Ilmu-Ilmu Peternakan. 25 (2): $28-35$.

Wijiastuti, T., E. Yuwono dan N. Iriyanti. 2013. Pengaruh pemberian minyak ikan Lemuru terhadap total protein plasma dan kadar hemoglobin (hb) pada ayam Kampung. J. Ilmiah Peternakan. 1 (1): 228-235.

Yamin, M. 2008. Pemanfaatkan ampas kelapa dan ampas kelapa fermentasi dalam ransum terhadap efesiensi ransum dan income over feed cost ayam pedaging. J. Agroland. 15 (2): 135 -139. 